\title{
The Impact of Tax Policies on Taxpayers Budget in Terms of Risk, Sensitivity and Volatility
}

\author{
Boloş Marcel Ioan, Otgon Cristian Ioan, Pop Răzvan Valentin \\ University of Oradea, Oradea, Romania
}

\begin{abstract}
Local and central governments are concerned to develop fiscal policies that are based on principles already enshrined in the literature as the principle of equity and/or the principle of fiscal appropriateness. Beyond these principles, the governments want to make sure that all taxpayers have the capacity to pay at maturity the tax debts owed to the public budget. In crisis situations, as recent experience has shown, governments adopt fiscal policy measures, with the sole purpose of procuring financial resources to cover the huge government budget deficits. In this situation, a natural question arises: Do governments need, for the elaboration of their fiscal policy, an analysis that takes into account the taxpayer's budget? Or is it sufficient that they confine only to the theoretical principles enshrined in the literature or the tax paying ability of the taxpayers? The answer can only be affirmative, because any taxpayer's budget is an inexhaustible source of resources for the public budgets. It is undisputed that in the taxpayer's budget, the tax expenditures coexist with other categories of expenditures such as consumption expenditures, durable expenditures and public utilities expenditures. Each expenditure type is risk-bearing. To study the structure of budget expenditures within the taxpayer, the authors suggest the use of three indicators innovative for the science of public finance: the risk, the sensitivity coefficient and the coefficient of volatility. Depending on the values registered by the three indicators of fiscal policies, expenditures can be classified as risky, volatile and sensitive which may lead to risks of failure to collect the taxes and/or to tax evasion. Innovative for the science of public finances is that the fundamentation of the fiscal policies is realized using the three indicators, the budget of the taxpayer and the networking between the categories of expenditures that fall within its budget structure.
\end{abstract}

Keywords: fiscal policy, risk, volatility, sensitivity, taxpayer budget, expenditure

\section{Introduction}

Nowadays the local and central governments in Central and Eastern Europe are preoccupied to elaborate measure plans which can lead to new sustainable economic development and also to get out of crisis. The economic crisis has hit the national economies. The aggregate demand has been severely damaged. Companies had to adjust their activities, many of which bankrupted. Along with these, budget deficits have appeared because

Boloş Marcel Ioan, Associate Professor, Department of Finance-Accounting, University of Oradea.

Otgon Cristian Ioan, Master, Department of Finance-Accounting, University of Oradea.

Pop Răzvan Valentin, Bachelor, Department of Finance-Accounting, University of Oradea.

Correspondence concerning this article should be addressed to Boloş Marcel Ioan, Oradea, Romania, Linistei street, 14, bl. PC 7, ap. 3. E-mail: marcel_bolos@yahoo.com. 
the national economies could not provide their financial resources in order to support the public expenditures. But these budget deficits, some of them out of control, have given serious headaches to the local and public governments. The measures taken to rationalize the public expenditures were quite unpopular. The salaries have been considerably diminished, for example Romania has decreased the salaries by $25 \%$ and increased the consumption taxes (VAT has increased in the majority of Central and Eastern Europe countries).

The IMF intervention was necessary in order to give "last resort" credits to avoid financial collapse or even the default of states. For example, Greece borrowed 100 billion euro in order to avoid the financial difficulties determined by the budget deficit financing, while Romania has contracted a credit worth 20 billion euro with the same destination. Many of the rationalizing measures determined a series of fiscal innovations. Hungary, for example, resorted to different taxation for banks and monopolies. And the examples can go on. Every country had a specific strategy to get out of problems. The common point of these strategies was: rationalizing the public expenditures, fiscal innovations, and financing budget deficits through capital infusions from IMF, EU, World Bank or BERD.

A natural question arises: What was the cause of these excessive deficits acted like a real tsunami in times of financial crisis? The answer is very simple. Influenced by the economic growth miracle Central and Eastern Europe countries had increased the public expenditures that were not based on a sustainable economic growth. The oversized expenditures were not matched by financial resources of the same level. The consequences did not occur when the economic crisis started. This is how public debts have exponentially increased so the imminent danger of this period, for the most of the Central and Eastern European countries, is a new type of crisis: "sovereign debt crisis".

The economic growth period in Central and Eastern Europe has brought a mentality change regarding the consumer's behavior. Until recently, it was impossible to overcome the CEE consumer's behavior, whose golden rule was that 35-45 years old consumers would buy durables from their savings. The American consumer's behavior, which resorts to credits to buy a house or a car, was now adapted. There are several implications regarding this behavior, the consumer can enjoy his purchased goods without expecting to save the necessary money. The workforce is permanently stimulated to seek new job opportunities in order to pay the credit annuity. The economy is based on goods and services demand stimulated and supported by the banks through credits.

Changing mentality by resorting to credit in order to buy durable goods has determined the appearance of a new category of expenditures. This refers to the expenditure with the credit annuity which is additional to the already mentioned consumer expenditures, tax expenditures and public services expenditures.

A portfolio of consumer spending was formed, in which consumer goods spending has an important percentage, approximately $60 \%$ (see Figure 1), followed by expenses for taxes and charges, that account for $15 \%-16 \%$. What is noticeable in the consumer's budget is that in the growth period, until the emergence of the global economic crisis, there was a new type of expense, that of durable goods, with an average of $14 \%$ share in the total budget, which confirms that, consumers have turned to loans to purchase durable goods and thereby there was a change in lifestyle and consumption mentality generating a continuous improvement of living conditions. Another important category of expenditure as a share of the consumer's budget is the expenditure on public services, about $15 \%$, which has an upward trend in the period under review due to the rising prices of public utilities (electricity, water, heat etc.). 
Each of the consumer's expenses generates a certain category of risk determined mainly by the risk that the spending will not take place. Each consumer's expense from his/her budget has a certain level of sensitivity showing how it reacts when the consumer changes its ratio in the total expenditures by one percent. Increases or decreases for a category of expenditure for a short period of time are measured through volatility. The risk, the sensitivity and the volatility characterize each category of the consumer's expense budget and central and local governments should be interested in their development in the context of fiscal policies which they develop.

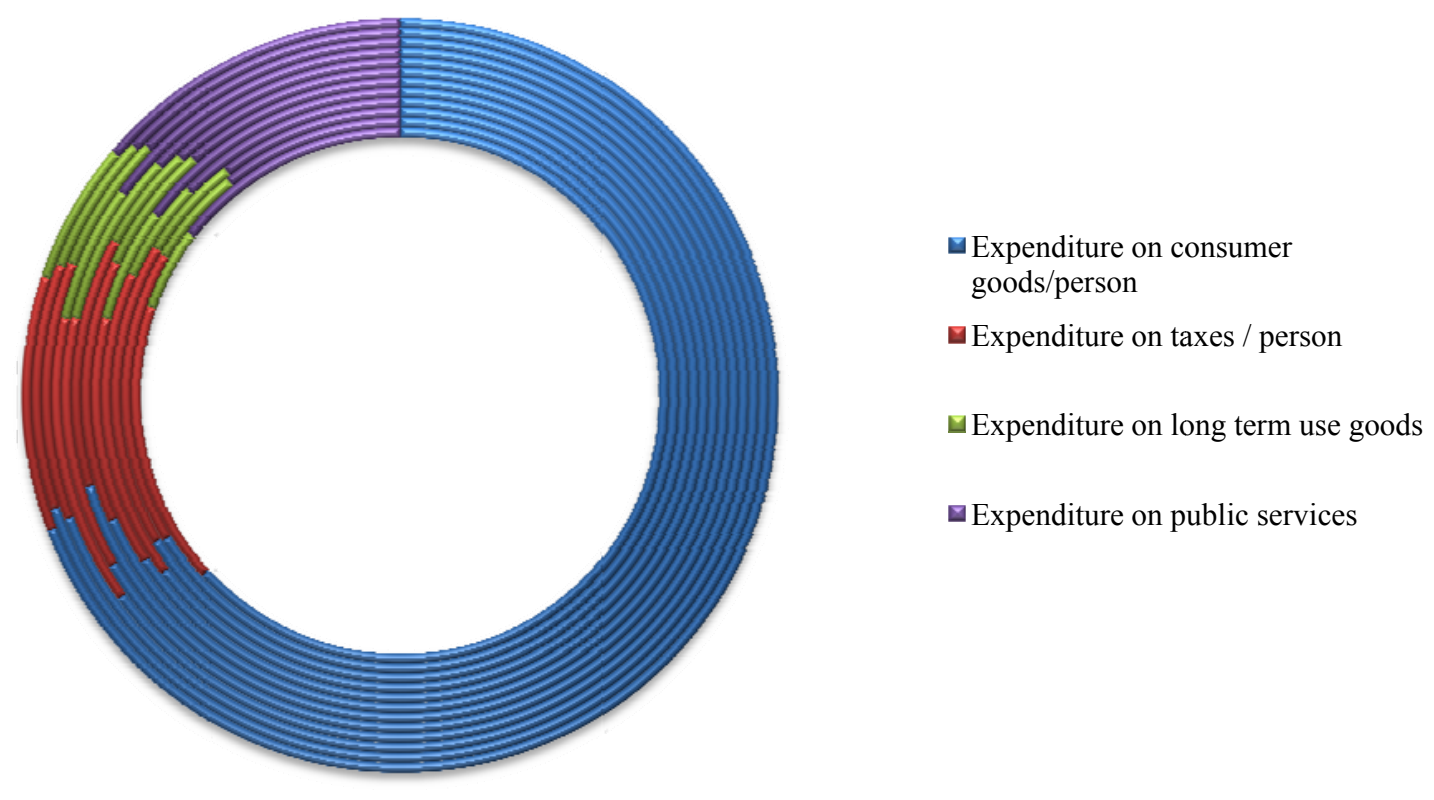

Figure 1. The evolution of the percentage of each type of expenditure in the whole portfolio.

\section{State of Knowledge}

The scientific literature provides us several papers regarding the impact of fiscal policies on the economic development and people's prosperity in order to find the optimal fiscal policy.

One of the most remarkable researches analyzes the optimal tax policy in a model where firms are internationally mobile (Johannes \& Clemens, 2011), showing that the optimal policy response to increasing firm mobility may be taxation, subsidization, or non-distortion of the marginal investment, depending on whether the mobile firms are more or less profitable than the average firm in the economy.

Also, another important research in the field refers to calculating an optimal mix of wage and bequest taxes with alternative parameter combinations (Grossmann \& Poutvaara, 2007). In all cases, the optimal wage tax rate is clearly higher than the optimal bequest tax rate, but the latter is generally positive when the required government revenue in the economy is sufficiently high.

The optimal fiscal package should be timely, large, lasting, diversified, contingent, collective, and sustainable (Spilimbergo, 2009): Timely, because the need for action is immediate; large, because the current and expected decrease in private demand is exceptionally large; lasting because the downturn will last for some time; diversified because of the unusual degree of uncertainty associated with any single measure; contingent, because the need to reduce the perceived probability of another "Great Depression" requires a commitment to do more, if 
needed; collective, since each country that has fiscal space should contribute; and sustainable, so as not to lead to a debt explosion and adverse reactions of financial markets.

Fiscal policy is also affecting the markets, the impact of fiscal policy from a different approach should be taken into consideration, the appetite for fiscal discipline has been steadily declining among most industrial countries (Ricardo, 2005). Even after controlling for cyclical effects, budgetary balances have been deteriorating both in the US and in Europe. In Japan, a string of large fiscal imbalances has severely undermined the sustainability of the fiscal stance.

In the past, fiscal profligacy would have been punished by markets with higher interest rates and, in some cases, also exchange rate depreciation. This is another good reason to find a way to calculate the taxpayers affordability.

Fiscal policy, the main instrument for the public authorities, has a great influence on economic cycles (Lopez-Pinto, 2001). The conclusion of a research that takes into consideration the effects of fiscal policies on capital accumulation and economic performance in a simple endogenous growth model with elastic labor supply by focusing on the implementability of a competitive equilibrium with productive public spending and distortionary taxation is that given a feasible exogenous fiscal policy, productive public spending can, at first, lead to positive short-run and long-run growth in the unique competitive equilibrium (Hyun, 2009). However, although strictly positive growth is possible in the short run, a Ramsey policy with productive public spending does not implement positive capital accumulation in the long run. Also, the local indeterminacy of Ramsey allocations, in conjunction with the global multiplicity, arises as an implementable competitive equilibrium with Ramsey policies: namely, a continuum of transitional dynamics and multiple balanced growth paths.

Extending income tax cuts and reducing the growth rhythm of government spending (excluding Social Security and Medicare), assuming that government expenditures are cut to avoid dramatic increases in government consumption relative to GDP in comparison to historical norms, would increase investment, employment, and output. However, postponing the implementation of tight spending controls would more than offset the positive benefits of lower tax rates on the size of the economy and leave future generations with fewer resources for private consumption and production (Diamond, 2005).

\section{Volatility and Sensitivity Calculation in the Study of Fiscal Policy Impact Over the Public Budget}

As already seen, in the Central and Eastern Europe the taxpayers' budget is characterized by a series of features specific to the economic boom period, but also by the constraints determined by the well-known financial crisis. As a consequence of economic boom met in the former communist countries but perhaps as a result of changing attitude of taxpayers, a significant proportion of expenses is starting to be held by those for durable goods. The latter takes the form of reimbursement credit rates and interest rates contracted by the taxpayers from banks in order to buy houses or durable goods.

The volatility and sensitivity calculation in order to study the impact of fiscal policies over the taxpayer's budget involves a series of hypotheses which represent the base of calculation and have as a goal the analysis of the inherent risk each expenditure category included in the taxpayers budget but also of the risk determined by the variation of weight held by some expenditures in the total budget. 
A natural question arises: What is the significance of total budget risk and how can this category of risk affect the fiscal policies which the governments are elaborating in accordance with the national development strategies?

There are several matters which we are trying to cover, supported not only by the theoretical formulations which will be found in this research paper but also by the elaborated calculation of the volatility and sensitivity within the study of fiscal policy.

In the terminology used in this research paper, global risk designates the risk that an expenditure, part of the total taxpayers budget, cannot be realized due to lack of funding source or other endogenous or exogenous factors which characterize the taxpayer's behavior. The greater the risk, the higher the probability for an expenditure not to be made. If this probability affects the tax expenditures the public budget can be put in difficulty on short and medium term by the taxpayer's risk of non-payment. As a consequence, fiscal policies make more sense if analyzed from the perspective of the inherent risk of each category of expenditure which constitutes the taxpayer's budget and also from the perspective of sensitivity analysis determined by fiscal policies when they produce an effect on the proportion of taxes in the taxpayer's total budget.

In order to test the impact of fiscal policies over the taxpayer's budget there were drawn a series of hypotheses, which are the basis for the sensitivity and volatility calculation and are characteristic for any consumer's budget.

First hypothesis starts from the idea that each group of expenditures, no matter if they are consumption expenditures $\left(C h_{c}\right)$, tax expenditures $\left(C h_{\text {imp,taxe }}\right)$, durable expenditures $\left(C h_{b f}\right)$, or public utility expenditures $\left(C h_{u p}\right)$, registers expenditures growth rate between two consecutive periods, $t_{0}$ respectively $t_{1}$, determined according to a relation of the following form:

$$
R_{c h}=\frac{C h_{t 1}-C h_{t 0}}{C h_{t 0}} \times 100
$$

Any positive values of the expenditures growth rhythm may reveal the taxpayer's propensity for a category of expenditure and hence a sort of behavior which can be based on consumption expenditures and/or durable expenditures, while the negative values signify a decreasing pace of allocating financial resources for that category of expenditure. In any situation the taxpayer's budget must be balanced, even if loans are contracted in order to provide the budget balance.

The second hypothesis is based on the fact that the sum of weights of every category of expenditure in the total budgets equals to one. It means that the taxpayer's budget can be written as a sum of expenditures consisting in consumer goods expenditures, tax expenditures, durable goods expenditures, public services expenditures, according to the taxpayer's budget equation of the form:

$$
B_{c}=C h_{c}+C h_{i m p, t a x e}+C h_{b f i}+C h_{u p}
$$

If equation (2) is divided to taxpayer's budget $\left(B_{c}\right)$, it results a sum of weights in the total budget, formed by the weight of consumption expenditures $\left(p_{c}\right)$, the weight of tax expenditures $\left(p_{f}\right)$, the weight of durable expenditures $\left(p_{b f i}\right)$ and also the weight of public utility expenditures $\left(p_{u p}\right)$, according to the following relation:

$$
1=p_{c}+p_{f}+p_{b f i}+p_{u p}
$$


In order to substantiate the global risk of taxpayer's budget, it is necessary to use a series of specific indicators which start from the average rhythm of total expenditures growth which is registered by the taxpayer $\left(\bar{R}_{c h}\right)$ and also from the variance of total expenditures which form the taxpayer's budget structure $\left(\sigma_{c h}\right)$. The average rhythm of total expenditures growth is obtained depending on the weight of expenditures specific to the taxpayer's behavior in his total budget $\left(p_{i}\right)$ and also on the average rhythm of specific expenditures between two consecutive periods $\left(\bar{R}_{C h i}\right)$. Also the variance of total expenditures which forms the taxpayer's expenditure structure is obtained depending on the weight $\left(p_{i}\right)$ of every category of specific expenditures, on the standard deviation (the inherent risk of each category of specific expenditures in taxpayer's budget), $\sigma_{C h i}^{2}$, and on the covariance between two pairs of specific expenditures $\left(\sigma_{c, f}\right)$.

We, thus, obtained the global risk equations which characterize the taxpayer's behavior. These equations are at the base of the study of the impact that fiscal policies have over the consumption goods budget, tax budget, durable goods budget and public utility budget and can be expressed as follows:

$$
\left\{\begin{array}{l}
\bar{R}_{C h}=p_{c} \times \bar{R}_{C}+p_{f} \times \bar{R}_{f}+p_{b f i} \times \bar{R}_{b f i}+p_{u p} \times \bar{R}_{u p} \\
\sigma_{C h}^{2}=p_{c}^{2} \times \sigma_{C}^{2}+p_{f}^{2} \times \sigma_{f}^{2}+p_{b f i}^{2} \times \sigma_{b f i}^{2}+p_{u p}^{2} \times \sigma_{u p}^{2}+2 p_{c} p_{f} \sigma_{C f}+2 p_{c} p_{b f i} \sigma_{C b f i}+2 p_{c} p_{u p} \sigma_{C u p} \\
2 p_{f} p_{b f i} \sigma_{f b f i}+2 p_{f} p_{u p} \sigma_{f u p}+2 p_{b f i} p_{u p} \sigma_{b f i u p} \\
1=p_{c}+p_{f}+p_{b f i}+p_{u p}
\end{array}\right.
$$

The above equations can be rewritten in the following general form:

$$
\left\{\begin{array}{l}
\stackrel{R}{R}_{C h}=\sum_{i=1}^{4} p_{i} \times \bar{R}_{C h i} \\
\sigma_{C h}^{2}=\sum_{i=1}^{4} p_{i}^{2} \times \sigma_{C h i}^{2}+2 \sum_{i=1}^{4} \sum_{j=1}^{4} p_{i} p_{j} \sigma_{i j} \\
1=\sum_{i=1}^{4} p_{i}
\end{array}\right.
$$

The study of fiscal policies' impact over the taxpayer's budget will be performed by measuring the sensitivity of consumer's global risk $\left(\sigma_{C h}\right)$ according to the changes in the tax expenditure weight $\left(p_{c}\right)$, according to the expression:

$$
\gamma=\frac{\partial \sigma_{C h}}{\partial p_{c}}
$$

In order to determine the sensitivity coefficient $(\gamma)$, it is necessary to establish the final form of consumer's global risk based on the general risk equation depending on expenditure's weight of consumption goods, durable goods, taxes and public services and also the specific risk determined through the medium of standard deviation $\left(\sigma_{C h i}^{2}\right)$ for each expenditure categories:

$$
\begin{aligned}
& \sigma_{C h}^{2}=p_{c}\left(p_{c} \sigma_{c}^{2}+p_{f} \sigma_{c f}+p_{b f i} \sigma_{c b f i}+p_{u p} \sigma_{c u p}\right)+ \\
& p_{f}\left(p_{f} \sigma_{f}^{2}+p_{c} \sigma_{c f}+p_{b f i} \sigma_{f b f i}+p_{u p} \sigma_{f u p}\right)+ \\
& p_{b f i}\left(p_{b f i} \sigma_{b f i}^{2}+p_{c} \sigma_{c b f i}+p_{f} \sigma_{f b f i}+p_{u p} \sigma_{b f i u p}\right)+ \\
& p_{u p}\left(p_{u p} \sigma_{u p}^{2}+p_{c} \sigma_{c u p}+p_{f} \sigma_{f u p}+p_{b f i} \sigma_{b f i u p}\right)
\end{aligned}
$$


The analysis of the expression of the consumer's global risk equation (5) from above reveals that global risk is depends on expenditures weight in the taxpayer's total budget $\left(p_{i}\right)$ and the risk specific to each expenditure category related to the taxpayer's total budget $\left(\sigma_{i C h}\right)$, which leads to the global risk evaluation of the form:

$$
\sigma_{C h}^{2}=p_{c} \sigma_{C C h}+p_{f} \sigma_{f C h}+p_{b f i} \sigma_{b f i C h}+p_{u p} \sigma_{u p C h}
$$

In these conditions and taking into account the possible changes in the tax expenditures, the sensitivity coefficient shall be determined starting from expression (6):

$$
\begin{aligned}
& \gamma=\frac{\partial\left(\sqrt{p_{c} \sigma_{C C h}+p_{f} \sigma_{f C h}+p_{b f i} \sigma_{b f C h}+p_{u p} \sigma_{u p C h}}\right)}{\partial p_{c}}=\frac{1}{2 \sigma_{C h}}\left(p_{c} \frac{\partial \sigma_{C C h}}{\partial p_{c}}+p_{f} \frac{\partial \sigma_{f C h}}{\partial p_{c}}+p_{b f i} \frac{\partial \sigma_{b f i C h}}{\partial p_{c}}+p_{u p} \frac{\partial \sigma_{u p C h}}{\partial p_{c}}\right) \\
& =\frac{1}{2 \sigma_{C h}}\left(p_{c} \sigma_{C C}+p_{f} \sigma_{f C}+p_{b f i} \sigma_{b f i C}+p_{u p} \sigma_{u p C}\right)=\frac{1}{2 \sigma_{C h}}\left(\sigma_{C C h}+\sigma_{C C h}\right)
\end{aligned}
$$

The final form of the sensitivity coefficient which will be used in the analysis of the impact of fiscal policies over the taxpayer's budget is given by a relation of the form:

$$
\gamma_{C}=\frac{\sigma_{C C h}}{\sigma_{C h}}
$$

The expression (10) provides a major advantage because the sensitivity analysis of central and local governments fiscal policies can be made taking into account the taxpayer's global risk which consider every expenditure categories specific to the taxpayer's needs for either consumption or durable goods.

In order to measure the taxpayer's global risk there shall be used the taxpayer's budget equations written in a matrix form, using the variance-covariance matrix $\left(\Omega_{n \times m}\right)$ and the column vector of every expenditure weights in the taxpayer's budget $\left(p_{i}^{T}\right)$ which in a simplified form can be written as:

$$
\left(\begin{array}{l}
\sigma_{C C h} \\
\sigma_{f C h} \\
\sigma_{b f i C h} \\
\sigma_{u p C h}
\end{array}\right)=\left(\begin{array}{l}
\sigma_{c c} \sigma_{c f} \sigma_{c b f i} \sigma_{c u p} \\
\sigma_{f c} \sigma_{f f} \sigma_{f b f i} \sigma_{f u p} \\
\sigma_{b f i c} \sigma_{b f f} \sigma_{b f i b f i} \sigma_{b f i u p} \\
\sigma_{u p c} \sigma_{u p f} \sigma_{u p b f i} \sigma_{\text {upup }}
\end{array}\right) \times\left(\begin{array}{c}
p_{c} \\
p_{f} \\
p_{b f i} \\
p_{u p}
\end{array}\right)
$$

With these calculation judgments, the sensitivity coefficient can be determined for each expenditure category which is part of the taxpayer's budget, in order to measure the risk specific to each expenditure category, compared to taxpayer's global risk. In contradistinction to the inherent risk also specific to each expenditure category, which is related to the values registered by each expenditure category in a previous period of time and is determined by the standard deviation, the sensitivity coefficient is influenced also by the covariance between the expenditure pairs which are part of the taxpayer's portfolio.

High values of sensitivity coefficient, specific to the tax expenditures, determined above, will indicate an increased level of risk of these expenditure categories not to be paid in time, while low values of this coefficient can be an expression of a high potential of financial resources, which can be fructified by the governments through additional revenues for the public budgets.

The sensitivity coefficient is highly dependent on two specific notions, which are innovative for the public finance domain, namely the expenditure risk and taxpayer's global risk. Explained in simple terms, the 
expenditure risk appoints the risk that an expenditure is not made by the taxpayer due to: lack of financial resources, taxpayer's specific behavior etc.. For public budgets, the taxpayer's risk of tax expenditure is equivalent to the risk of not collecting the tax revenues. If this risk is amplified by a certain intensity of financial crisis, the probability that the public budget shall register deficits or liquidity crisis is quite high.

The risk of a specific expenditure relative to the taxpayer's total budget is the second form of the specific risk for each expenditure category which is a part of taxpayer's total budget. The advantage of studying this form of risk is that it depends on the intensity of the connections between a studied expenditure and the other categories of expenditure. These connections are studied through the statistical covariance and indicate the "behavior" of a certain expenditure category as compared to the taxpayer's total expenditures. The major advantage of this category of risk is given by the fact that, by the help of covariance, one can study the way a certain category of expenditure behaves as compared to the other expenditure categories.

As regards the taxpayer's global risk, it offers information related to the taxpayer's risk of not his budget. When taxpayer's budget is risky, the central and local fiscal policies are more exposed to the risk of not collecting the tax debts. That is why a fundamental element, even strategic, in the substantiation of fiscal policies, will be the very intensity of the global risk of the taxpayer's budget in order to detect in due time potential risks of not realizing the planned budget.

It can be noticed that taxpayer's global risk is a homogeneos function that depends on the weight vector $\left(p_{c}, p_{f}, p_{b f i}, p_{u p}\right)$, which means that the Euler formula can be applied and the taxpayer's global risk equation can be rewritten as:

$$
\sigma_{C h}=p_{c} \frac{\partial \sigma_{C C h}}{\partial p_{c}}+p_{f} \frac{\partial \sigma_{f C h}}{\partial p_{f}}+p_{b f i} \frac{\partial \sigma_{b f i C h}}{\partial p_{b f i}}+p_{u p} \frac{\partial \sigma_{u p C h}}{\partial p_{u p}}=p_{c} \frac{\partial \sigma_{C h}}{\partial p_{c}}+p_{f} \frac{\partial \sigma_{C h}}{\partial p_{f}}+p_{b f i} \frac{\partial \sigma_{C h}}{\partial p_{b f i}}+p_{u p} \frac{\partial \sigma_{C h}}{\partial p_{u p}}
$$

Taking into account the sensitivity coefficient established through expression (9) the taxpayer's global risk can be written depending on the coefficients $\left(\gamma_{i}\right)$ and the weights of specific expenditures in the taxpayer's total budget $\left(p_{i}\right)$, in the following formula:

$$
\sigma_{C h}=\gamma_{c} p_{c}+\gamma_{f} p_{f}+\gamma_{b f i} p_{b f i}+\gamma_{u p} p_{u p}
$$

If expression (8) is divided by $\sigma_{C h}$ and the sensitivity coefficient is replaced with the ratio between the risk specific to each category of expenditure $\left(\sigma_{i C h}\right)$ and the taxpayer's global risk $\left(\sigma_{C h}\right)$, a new form of taxpayer's global risk is obtained:

$$
1=p_{c} \frac{\sigma_{C C h}}{\sigma_{C h}^{2}}+p_{f} \frac{\sigma_{f C h}}{\sigma_{C h}^{2}}+p_{b f i} \frac{\sigma_{b f i C h}}{\sigma_{C h}^{2}}+p_{u p} \frac{\sigma_{u p C h}}{\sigma_{C h}^{2}}
$$

The coefficients in expression (14) are called volatility coefficients and are determined as a ratio between the specific risk of a certain risk category in the total budget $\left(\sigma_{i C h}\right)$ and the standard deviation of taxpayer's expenditures $\left(\sigma_{C h}^{2}\right)$ according to the relation:

$$
\beta_{i}=\frac{\sigma_{i C h}}{\sigma_{C h}^{2}}
$$

The volatility coefficients determined for each expenditure category which is part of the taxpayer's budget offer information related to the risk of alterations in the level (value) registered for an expenditure in a short 
period of time. High values of the volatility coefficient will reflect a high risk for a category of expenditure that is part of the taxpayer's budget, which can modify its value in a short period of time, while the low (diminished) values of volatility coefficients reveal a low risk and thus a low probability that a category of expenditure, that is comprised in the taxpayer's structure, could modify its value in a short period of time.

Sensitivity and volatility are two coefficients which provide the local and central governments with information regarding the taxpayer's risk of not paying his taxes. This category of risk is extremely important for every government that is substantiating its fiscal policy. If the taxpayer is registering high sensitivity coefficients then the fiscal policy turns to be quite risky.

\section{Types of Fiscal Policies Established With Respect to the Taxpayer's Risk}

The calculations, the hypotheses, and the rules exposed above lead to the conclusion that every fiscal policy made by central or local governments has to be substantiated not only on the affordability of taxpayers but also on the risk of not paying. This risk occurs because the taxpayer doesn't finance sole a category of expenditure that regards the taxes. The latter is added to by the consumption goods, durable goods, public utility expenditures which represent nothing more than expenditures for meeting the needs of a regular taxpayer. This way, the taxpayer is acting in the market, in his bivalent nature from two points of view, as a consumer and as a taxpayer. The constraints resulted from financing the expenditures are limited to the taxpayer's income over a certain period of time. These constraints often generate the occurrence of risk of non-payment as the income growing speed is inferior to the expenditure growing speed.

There are three categories of indicators which are at the basis of fiscal policy substantiation depending on the risk which appears in the taxpayer's budget. The indicators result from the above hypotheses and calculations, and they are: the inherent risk of an expenditure category, the sensitivity coefficient and the volatility coefficient of expenditures which are part of taxpayer's budget structure.

The inherent risk of each expenditure category, determined by the standard deviation, offer the local and central governments information related to the taxpayer's risk of not paying. The higher the values of this risk, the more intense the risk of not paying is acting. The major disadvantage of this indicator is the fact that it doesn't take into consideration other expenditure categories which are part of taxpayer's budget and moreover it does not measure the specific risk for each expenditure relative to the total budget.

In order to offer complete information about the taxpayer's risk, which local and central governments cannot neglect, there were introduced two specific notions regarding the global risk and the specific risk for each category of expenditure part of taxpayer's budget. The global risk, as shown before, represents that certain category which can help in obtaining information related to the probability of the taxpayer's budget to collapse. The specific risk of an expenditure category provides information about the "behaviour" of this expenditure as compared to the other ones which compose the taxpayer's budget. Regardless of the calculation and the interpretation of the indicators related to the taxpayer's risk, these indicators can succesfully be used with success in the sensitivity and volatility calculation of the coefficients, used by the local and central governments for fiscal policy substantiation. While the sensitivity coefficients contribute to testing the way a expenditure category behaves relative to the taxpayer's total budget when a percent of the weight of these expenditures in the total budget changes, the volatility coefficient provides information about the probability of an expenditure to change 
in a short period of time.

Depending on the values which are registered by the inherent risk of expenditures and the values of sensitivity and volatility coefficients for these expenditures, we can distinguish the particularities of the types of fiscal policies.

(1) If $\sigma_{f}^{2} \geq\left(\sigma_{c, b f i, u p}^{2}\right), \gamma_{f} \geq\left(\gamma_{c, b f i, u p}\right), \beta_{f} \geq\left(\beta_{c, b f i, u p}\right)$, the fiscal policy is risky and unstable and the fiscal expenditures are volatile in comparison with the other expenditures. The volatility is high. The risk of not collecting the fiscal debts is maximum. The government has to review the fiscal policy to monitor and control the risk of not collecting the tax debts.

(2) If $\sigma_{f}^{2} \geq\left(\sigma_{c, b f i, u p}^{2}\right), \gamma_{f} \leq\left(\gamma_{c, b f i, u p}\right), \beta_{f} \geq\left(\beta_{c, b f i, u p}\right)$, the fiscal policy is also risky, stable, with high volatility. The tax expenditures behave quite well as compared to the other expenditures due to the low level of sensitivity. The risk of not collecting the tax debts is high. Volatility registers high levels. The government's fiscal policy has to be monitored because there is a perspective of increasing tax expenditures on short term.

(3) If $\sigma_{f}^{2} \geq\left(\sigma_{c, b f i, u p}^{2}\right), \gamma_{f} \leq\left(\gamma_{c, b f i, u p}\right), \beta_{f} \geq\left(\beta_{c, b f i, u p}\right)$, the fiscal policy is risky, stable, with low volatility. Regarding the global risk, tax expenditures behave quite well as compared with the other expenditures. The risk of not collecting the tax debts is in acceptable limits. Volatility is low. The government's fiscal policy has to be monitored from the perspective of the evolution of the inherent risk of tax expenditures.

(4) If $\sigma_{f}^{2} \geq\left(\sigma_{c, b f i, u p}^{2}\right), \gamma_{f} \leq\left(\gamma_{c, b f i, u p}\right), \beta_{f} \geq\left(\beta_{c, b f i, u p}\right)$, the fiscal policy is also risky, unstable, but with low volatility. The tax expenditures are extremely sensitive in report to the other expenditures which means that an increase by one percent in tax expenditure is answered by an increase in the global risk. The volatility is quite low; yet, the risk of not collecting the tax debts stays high.

(5) If $\sigma_{f}^{2} \geq\left(\sigma_{c, b f i, u p}^{2}\right), \gamma_{f} \leq\left(\gamma_{c, b f i, u p}\right), \beta_{f} \geq\left(\beta_{c, b f i, u p}\right)$, the fiscal policy is characterized by a diminished risk, unstable and highly volatile. There is a problem in these situations due to the unstable characteristic of fiscality. It is possible that for short-term periods of time the tax expenditures register high values, due to the high volatility. The risk of not collecting the tax debts can be a major problem when the tax expenditures grow.

(6) If $\sigma_{f}^{2} \geq\left(\sigma_{c, b f i, u p}^{2}\right), \gamma_{f} \leq\left(\gamma_{c, b f i, u p}\right), \beta_{f} \geq\left(\beta_{c, b f i, u p}\right)$, the risk of fiscal policy is still diminished, the fiscal policy is stable due to the low level of sensitivity and high volatility. The behaviour of tax expenditures compared with the other expenditures is good due to the low sensitivity. Volatility is high. The fiscal policy has great chances to be succesfully implemented even if there is a perspective of increasing tax expenditures for short-time periods.

(7) If $\sigma_{f}^{2} \geq\left(\sigma_{c, b f i, u p}^{2}\right), \gamma_{f} \leq\left(\gamma_{c, b f i, u p}\right), \beta_{f} \geq\left(\beta_{c, b f i, u p}\right)$, the fiscal policy risk is also diminished, but the fiscal policy is stable, due to low level of sensitivity which tax expenditures register. The volatility is low. The behaviour of tax expenditures as compared to the other expenditures is good with respect to the taxpayer's global risk. It's the type of fiscal policy with the greatest sensitivity and volatility indicators, with great chances to be succesfully implemented, and a low risk of not collecting the tax debts.

(8) If $\sigma_{f}^{2} \geq\left(\sigma_{c, b f i, u p}^{2}\right), \gamma_{f} \leq\left(\gamma_{c, b f i, u p}\right), \beta_{f} \geq\left(\beta_{c, b f i, u p}\right)$, the risk of fiscal policy is low and unstable. The volatility is also low. The tax expenditures behave rather undesirably as compared with the other expenditures, 
due to high level of sensitivity. There is a risk of not collecting the tax debts when the weight of tax expenditures in the taxpayer's total budget changes.

The combination between risk, sensitivity and volatility coefficients, offer the governments further information in order to substantiate their fiscal policies, so that the risk of not collecting the tax debts could be controled. It is noticeable the fact that the risk, the sensitivity and the volatility of fiscal policies could not always register values which can be framed in the eight fiscal policy typologies. In these situations the values of the indicators should be analyzed in correlation with the values obtained for each expenditure category which is part of taxpayer's total budget. The combination between sensitivity and volatility coefficients is also useful to detect the tax evasion which can be active in the circumstances when the risk is high and the sensitivity and the volatility levels are high as well.

Nowadays, the risk of not collecting the tax debts and tax evasion are major concerns for the local and central governments all over the world. There is a question which has to be answered: To what extent do fiscal policies need to be reviewed in order to keep the taxpayer's fiscal comfort? It is a question and also a research subject which will be treated in our future research activities.

\section{Testing the Types of Fiscal Policies for the Taxpayers From Central and Eastern Europe}

In order to test the impact of fiscal policies over the taxpayer's budget, the expenditures of the taxpayer were grouped in four major categories, namely the consumption expenditures, tax expenditures, durables expenditures, and public utility expenditures. The database of this analysis is made of information provided by the national institutes of statistics. The calculation of risk, sensitivity coefficient and volatility coefficient can be applied for each series of data constituted with the purpose of analyzing the sustainability of local and central government's fiscal policies.

The first indicator calculated was the growth in the rate of expenditures between two consecutive periods, the time slot for the analysis being 2008-2010. The results are presented in Appendix A. It is noticeable that the most spectacular growth rhythm was registered by the durables, which after an ascending trend in 2008-2009 it is start to register a decrease in the late 2010. The consumers abandoned the idea of buying durables as a result of the fact that the consumer's income was constant, in the analyzed period, with a slight decrease. The durables were a disposable variable as their income was diminished. The general characteristic of growth rhythms, in periods of economic crisis, for the analyzed expenditure categories was the emergence, as an increasing rhythm was followed by a descendent evolution, even for short period of time. Regarding the public utility expenditures they had an increasing trend due to the fact that in Central and Eastern Europe the prices of public utilities are established in monopoly conditions. An emergence of fiscal expenditures was observed in the period analyzed and that was due to increased tax rates, as a last resort solution to avoid financial collapse or excessive budget deficits.

The risk of expenditures is the second indicator which has been calculated and analyzed for each expenditure category that was part of taxpayer's budget. The less risky expenditure turns out to be the consumption expenditures, which are the most significant part of the total budget. The reason is that in the analyzed period the consumption expenditures are almost constant and the growth rhythms of this type of expenditures registered the same trend. The durables expenditures proved to be extremely risky because, besides the fluctuant growth rhytms, they have registered high values of risk (in quarter IV $\sigma_{b f i}^{2}=4,293.04209$ ). 
The situation is explained by the fact that during economic boom, the population resorted to credits to purchase durables, and then the economic crisis changed the behaviour of the consumer who abandoned the idea of buying durables, because it was the only disposable type of expenditure. Regarding the tax expenditures they registered high values of risk especially in the last period analyzed (year 2010). The tax expenditures were ranked in the third place after durable expenditures and public utility expenditures. The risk evolution for each expenditure is presented in Figure 3.

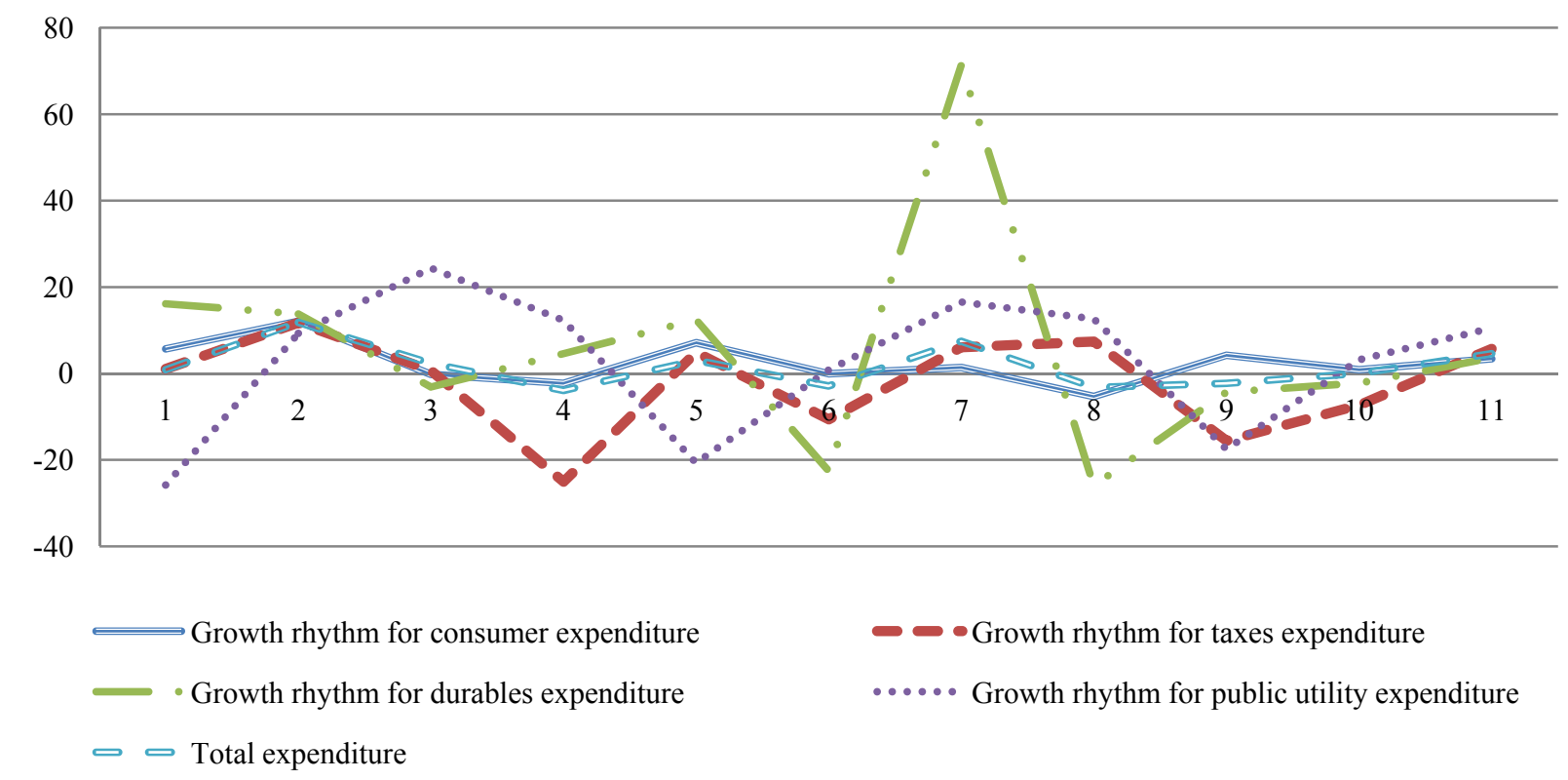

Figure 2. The growth rythm of consume expenditure (\% from a trimester to another).

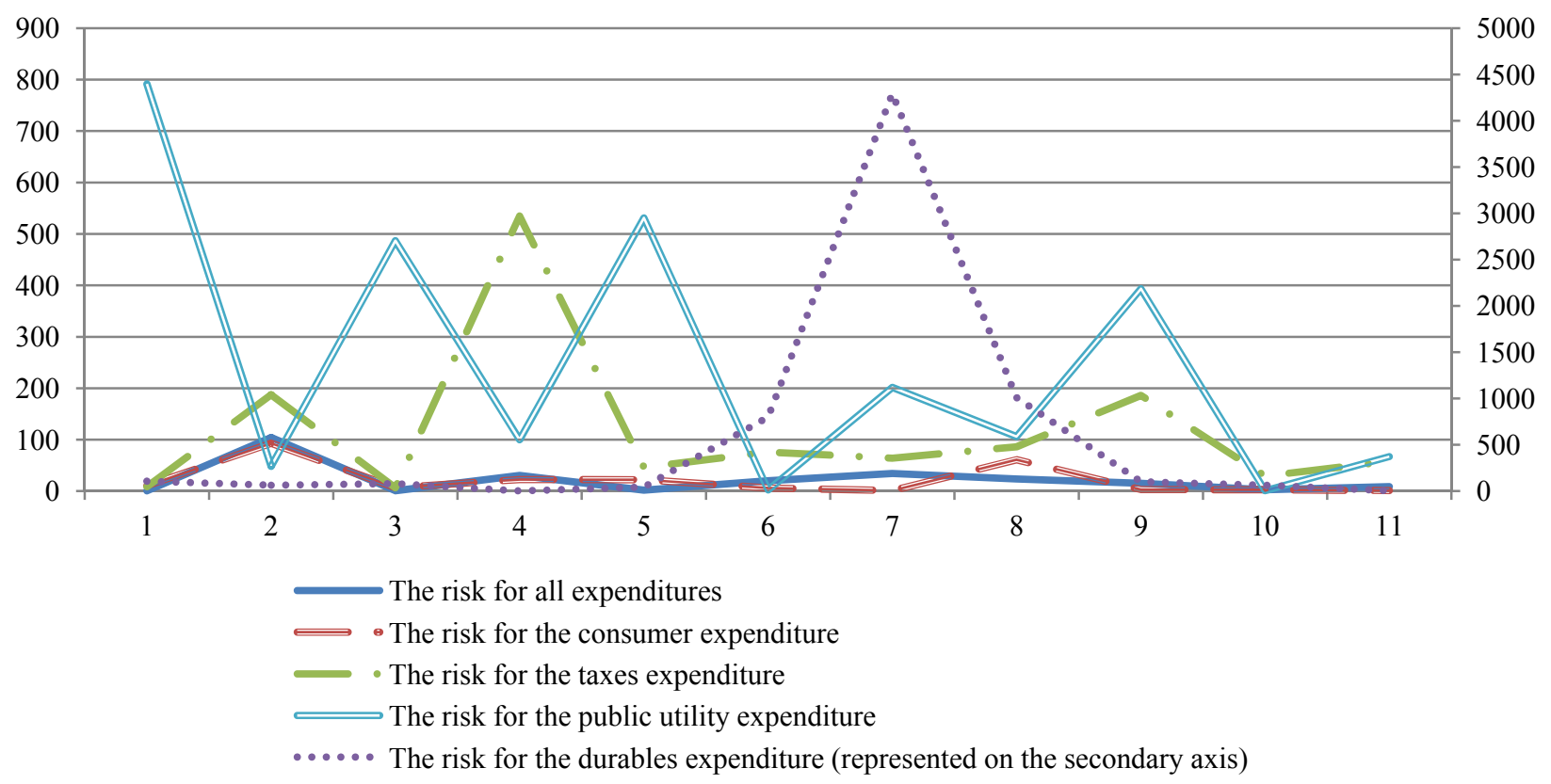

Figure 3. The evolution of the risks for each expenditure (\% from a trimester to another). 
The sensitivity and volatility coefficients for each expenditure category are the third category of indicators analyzed, the values of which are presented in Table 1.

Table 1

The Situation of Sensitivity and Volatility Coefficents for Each Expenditure Category

\begin{tabular}{lccc}
\hline Specification & Risk at the level of period & Sensitivity at the level of period & Volatility at the level of period \\
\hline Total expenditures & 22.0287846 & & \\
Consumption expenditures & 20.87507 & 0.10530504 & 0.00079995 \\
Tax expenditures & 116.6408 & 0.25906198 & 0.00196797 \\
Durables expenditures & 597.26563 & 0.53432052 & 0.00405898 \\
Public utilities expenditures & 248.107557 & 0.10131246 & 0.00076962 \\
\hline
\end{tabular}

The most sensitive expenditures for the period analyzed remained the durable expenditures. The calculation leads us to the conclusion that a one percent change in the weight of durables expenditures determines an increase of $0.53 \%$ in the global risk of the taxpayers budget. The weight of tax expenditures in the total budget will itself determine an increase of the global risk of $0.25 \%$. Finally, the sensitivity calculation shows that even if public utility expenditures are quite risky, they behave better compared to the other expenditures due to low level of sensitivity which is registered in the analyzed period.

The volatility coefficient registered the highest values for the durable expenditures. It means that the probability of changing the values of durables expenditures in the total budget is very high. The hypothesis of this change in value is confirmed by the emergent growth rate which was registered during the analyzed period (2008-2010).

The tax expenditures register quite high levels in what volatility is regarded after durables expenditures. Any increase of tax expenditures will have consequences in the volatility of this type of expenditure. The causes for a high volatility can be many. One of them can be the stagnation or even the reduction of the income which taxpayers earn during the analyzed period.

The consumption expenditures remained the less volatile. The explanation consists in the low level of risk which consumption expenditures registered but also in the low level of sensitivity registered as compared to the other expenditure categories.

The general characteristic of Eastern Europe fiscal policies related to the taxpayer's total budget is that it was quite risky registering the third highest level of risk, after durable expenditures and public utility expenditures. The volatility is quite high which means that any modification of tax expenditure weight in the total budget becomes risky. Central and local governments must be prudent in the elaboration of fiscal policies to avoid the risk of not collecting the tax debts or the phenomena of tax evasion which can manifest among the taxpayers. Besides the high sensitivity of fiscal policies, Eastern Europe registers an interesting particularity determined by the high volatility of tax expenditures. This means that the latter are likely to change their values on short-term. Any modification of fiscality as a weight in taxpayer's budget is followed by a certain response which can manifest under the form of not collecting the tax debts as they were projected. The greatest constraint regarding fiscality is manifest when the income evolution is flat or decreasing especially in the time of economic crisis. The influence of income stagnation on the fiscal risk and on sensitivity and volatility of risk with the tax expenditures is a future reseach direction which shall be explored within further research activities. 
From the perspective of risk, sensitivity, volatility the tax expenditures were analyzed on their structure. In order to perform this analysis tax expenditures were grouped in four major subgroups, namely, wage tax expenditures, pension contribution expenditures, health contribution expenditures and unemployment expenditures. The results are presented in Table 2.

Table 2

Risk, Sensitivity and Volatility Calculation for Eastern Europe Tax Expenditures

\begin{tabular}{llll}
\hline Specification & Risk at the level of period & Sensitivity at the level of period Volatility at the level of period \\
\hline Tax expenditure & 11.65603 & & 0.0108352 \\
Wage tax expenditure & 18.5823 & 0.3962421 & 0.0064601 \\
Pension contribution expenditure & 8.781152 & 0.2362452 & 0.0087524 \\
Health contribution expenditure & 12.16907 & 0.3200744 & 0.0012972 \\
Unemployment expenditure & 10.97704 & 0.0474382 & \\
\hline
\end{tabular}

The most risky expenditures remained the wage tax expenditures with a level of risk of $\sigma_{s}^{2}=18.5823$, which simultaneously register the highest levels of sensitivity, $\gamma_{s}=0.3962421$, and respectively of volatility, $\beta_{s}=0.0108352$. This means that any modification in central government's fiscal policy, in the sense of a transition from a fiscal policy based on flat tax to a fiscal policy based on progressive tax may lead to a great risk of not collecting the tax debts. Also a high risk level was registered by the health contribution expenditures. The level of sensitivity and volatility of this subcategory makes the modification of weight in the total budget lead to a risk of not collecting the specific tax debts owed to the social security budget.

The structural analysis of tax expenditure structure based on risk, sensitivity and volatility coefficients provides the governments with additional regarding the most sensitive, risky and volatile expenditure, so that they could be more cautious in the elaboration of fiscal policies.

\section{Conclusions, Future Research Directions}

The fiscal policy of central and local governments should not be based only on equity principles and/or fiscal rightness. It is not sufficient to produce a fair wealth taxation or a fair taxation of the work and of the capital if these are not accompanied by a detailed analysis of taxpayer's budget. And this budget has a series of constraints determined by the income level which taxpayers register and also by the behaviour of the taxpayer acting as a consumer on the products and services market.

Each expenditure category is included in the taxpayer's budget regardless of its nature: consumption expenditures, durables expenditures, tax expenditures and/or public utility expenditures registering a certain level of risk. This risk can be manifested under two forms: when the taxpayer involves in the expenditure and the public budget collects the tax debts or on contrary when the taxpayer does not make the whole expenditure in which case the tax debts register an increasing trend. The measurement of each expenditure risk was performed using the standard deviation, and the results obtained in the analysis period 2008-2010 lead to the hypothesis that the riskiest category of expenditure remains the durables expenditure followed by the public utility expenditures. On the third place as size, it turns out to come the tax expenditures, that register a risk of $\sigma_{f}^{2}=116.6408$ which implies that Eastern Europe countries must be cautious in the elaboration of fiscal policies, because there is a risk for taxes not to be collected totally at their maturity. 
This form of risk measurement is not sufficient, because the expenditure categories are interdependent. The measurement of the interdependency between the expenditure categories leads to another indicator for the analysis of the fiscal policies, known as sensitivity coefficient. The indicator whose formula was calculated in this research paper measures the risk of an expenditure category relative to the total taxpayer's budget when there is a modification of one percent in the weight of a expenditure category. The more sensitive an expenditure category is, the higher is the risk not to make that expenditure. In the period analyzed, tax expenditures registered a sensitivity value of $\gamma_{f}=0.25906198$ which leads to the hypothesis that any modification by one percent of tax expenditures determines a taxpayer's global risk increased by $0.25 \%$. By size the tax expenditures are ranked in the second position, in what sensitivity is concerned after durables expenditures.

The last indicator analyzed and determined for the fiscal policies was the volatility coefficient. This measures the probability that an expenditure included in the taxpayer's budget modifies its value in a short period of time. From the perspective of volatility, the tax expenditures were ranked on the second position after durable expenditures with a coefficient, $\beta_{f}=0.00196797$.

The general conclusion is that Eastern Europe's fiscal policies were pretty risky from the perspective of taxpayer's budget. The sensitivity, quite high, makes the fiscal policies elaborated be really hard to implement especially if they lead to increased tax rates. At the same time, volatility shows an increase in tax expenditures on short-term caused especially by the stagnation or even reduction of taxpayer's income.

The risk, the sensitivity and the volatility of tax expenditures in relation with the taxpayer's budget provide complete information for local and central governments related to the fiscal policies elaborated. The successful implementation of a fiscal policy also depends on the value of these indicators. In order to avoid the risk of not collecting the tax debts and the phenomena of tax evasion the governments have to monitor the value of these indicators so that avoiding measures can be taken by the central and local governments.

If the fiscal policy is risky the analysis can be continued through the calculation of risk, sensitivity and volatility for each expenditure category which is part of the fiscal policy. To perform this type of factorial analysis, the tax expenditures were grouped in wage tax expenditures, pension contribution expenditures, health contribution expenditures and unemployment expenditures. The calculation leads to the hypothesis that the riskiest expenditure category is wage tax registering a risk $\sigma_{s}^{2}=18.5823$, a sensitivity coefficient $\gamma_{s}=0.396242$ and a volatility coefficient $\beta_{s}=0.108352$. High values of risk, sensitivity and volatility can, as we mentioned, cause difficulties to the change in fiscal policies of central governments given by the transition from a taxation mechanism based on flat tax to a taxation mechanism based on progressive taxes.

Regardless of the information provided to the central and local governments, through the calculation of risk, sensitivity coefficient, volatility coefficient, there still stays as a future research direction, the study of fiscal policy boundaries and the impact of stagnating or reducted incomes on the risk of not collecting the tax debts. An important direction of research is represented by the calculation of expenditure efficiency frontier included in the taxpayer's budget having as a starting point the calculation hypothesis for the Markowitz efficiency frontier for financial markets.

\section{References}

Alm, J., \& Michael, Mc. (2004). Tax compliance as a coordination game. Journal of Economic Behavior and Organization, 54(3), 
297-312.

Altăr, M. (2002). Teorie portofoliului, Editura Academiei de Studii Economice. Bucharest.

An Brederode, R. (2009). Systems of general sales taxation: theory, policy and practice. Alphen/Rijn: Kluwer Law International.

Audubach, A. J. (1999). Public finance in theory and practice. In J. Slemrod (Ed.), Tax policy in the real world. Cambridge Mass:

Cambridge University Press.

Charness, G., \& Matthew, R. (2002). Understanding social preferences with simple tests. Quarterly Journal of Economics, 117(3), 817-869.

Chittenden, F., \& Foster, H. (2008). Perspectives on fair tax. Certified Accountants Educational Trust. London.

Cowell, F. A., \& James P. F. G. (1988). Unwillingness to pay: Tax evasion and public good provision. Journal of Public Economics, 36(3), 305-321.

Cox, J. C., \& Vjollca, S. (2007). On modeling voluntary contributions to public goods. Public Finance Review, 35(2), $311-332$.

Diamond John, W. (2005). Dynamic effects of extending the 2001 and 2003 income tax cuts. International Tax and Public Finance, 12(2).

Easterly, W., \& Rebelo, S. (1993). Fiscal policy and economic growth. Journal of Monetary Economics, 32(3), 417-458.

Faini, R. (2005, March). Fiscal policy and interest rates in Europe. Economic Policy, CEPR, CES, MSH, 21(47), 443-489.

Farrokh, K. L. (2010). Macroeconomic policy: Demystifying monetary and fiscal policy (2nd ed.). Springer.

Heyne, P. T., Boettke, P. J., \& Prychitko, D. L. (2002). The economic way of thinking (10th ed.). Prentice Hall.

Hyun, P. (2009). Ramsey fiscal policy and endogenous growth. Economic Theory, 39(3).

Johannes, B., \& Clemens, F. (2011, March). Optimal tax policy when firms are internationally mobile. International Tax and Public Finance, 18(5), 580-604.

Musgrave, R. A., \& Peggy, B. (1973). Public finance in theory and practice. McGraw Hill.

Ramey, V. (2009). Identifying government spending shocks: It's all in the timing. NBER working paper 15464, National Bureau of

Economic Research, Cambridge.

Slemrod, J. (1999). Tax policy in the real world. Cambridge: Cambridge University Press.

Sole Lopez-Pinto, J. (2001). Fiscal policy and the Spanish business cycle. Spanish Economic Review, 3(4).

Spilimbergo, A., Steven, S., Olivier, J. B., \& Carlo, C. (2009, February). Fiscal policy for the crisis. Ifo Working Paper Series, 10(2), 26-32.

Volker, G., \& Poutvaara, P. (2007). Pareto-improving bequest taxation. International Tax and Public Finance, 16(5).

\section{Appendix A: Monetary Units}

Table A1

The Values for Expenditure and Revenues in the Period 2008-2010, for Each Trimester

\begin{tabular}{llllllll}
\hline & $\begin{array}{l}\text { Monthly total } \\
\text { expenditure/ } \\
\text { person }\end{array}$ & $\begin{array}{l}\text { Expenditure on } \\
\text { consumer } \\
\text { goods/person }\end{array}$ & $\begin{array}{l}\text { Expenditure on } \\
\text { taxes/person }\end{array}$ & $\begin{array}{l}\text { Expenditure on } \\
\text { long term use } \\
\text { goods }\end{array}$ & $\begin{array}{l}\text { Expenditure on } \\
\text { public services }\end{array}$ & $\begin{array}{l}\text { Total } \\
\text { revenues/ } \\
\text { household }\end{array}$ & $\begin{array}{l}\text { Total } \\
\text { revenues/ } \\
\text { person }\end{array}$ \\
\hline 2008 Trimester 1 & 619.28 & 391.49062 & 106.597011 & 31.1447107 & 90.047658 & $1,647.73$ & 612.679969 \\
2008 Trimester 2 & 624.38 & 413.737662 & 107.684998 & 36.1634542 & 66.7938851 & $1,753.88$ & 650.92733 \\
2008 Trimester 3 & 698.21 & 463.725684 & 120.354962 & 41.1354959 & 72.9938577 & $1,889.2$ & 732.521246 \\
2008 Trimester 4 & 714.58 & 462.812093 & 121.130079 & 39.8469388 & 90.7908891 & $1,969.77$ & 733.133801 \\
2009 Trimester 1 & 686.58 & 452.160111 & 90.7902656 & 41.6719515 & 101.957672 & $1,895.66$ & 728.744019 \\
2009 Trimester 2 & 707.3 & 484.39481 & 95.2171555 & 46.8613622 & 80.826672 & $2,033.66$ & 781.276258 \\
2009 Trimester 3 & 686.97 & 484.125755 & 85.0959617 & 36.3065675 & 81.4417158 & $1,977.71$ & 773.415139 \\
2009 Trimester 4 & 738.25 & 490.88497 & 90.2727726 & 62.1956405 & 94.8966171 & $1,986.13$ & 767.687698 \\
2010 Trimester 1 & 714.39 & 464.577994 & 96.9219384 & 46.0314147 & 106.858653 & $2,000.34$ & 776.968021 \\
2010 Trimester 2 & 698.21 & 484.174605 & 81.8401709 & 44.0594211 & 88.1358028 & $2,038.37$ & 791.481469 \\
2010 Trimester 3 & 698.21 & 488.330541 & 75.8511141 & 43.0818505 & 90.9464945 & $1,955.03$ & 773.356994 \\
2010 Trimester 4 & 730.21 & 504.908211 & 80.1776807 & 44.6267907 & 100.497318 & $1,954.98$ & 770.438742 \\
\hline
\end{tabular}


Table A2

The Growth Rhythm From a Trimester to Another, for Each Expenditure

\begin{tabular}{|c|c|c|c|c|}
\hline & $\begin{array}{l}\text { Growth rhythm for } \\
\text { consumer expenditure }\end{array}$ & $\begin{array}{l}\text { Growth rhythm for taxes } \\
\text { expenditure }\end{array}$ & $\begin{array}{l}\text { Growth rhythm for } \\
\text { durables expenditure }\end{array}$ & $\begin{array}{l}\text { Growth rhythm for } \\
\text { public utility expenditure }\end{array}$ \\
\hline Trimester 2/1 2008 & 5.68265016 & 1.02065437 & 16.1142723 & -25.82385 \\
\hline Trimester 3/2 2008 & 12.0820574 & 11.765765 & 13.748802 & 9.2822458 \\
\hline Trimester 4/32008 & -0.19701107 & 0.6440255 & -3.1324701 & 24.381547 \\
\hline Trimester 1 2009/4 2008 & -2.30157824 & -25.0472992 & 4.58005748 & 12.299453 \\
\hline Trimester 2/1 2009 & 7.12904538 & 4.87595212 & 12.4530062 & -20.72527 \\
\hline Trimester 3/2 2009 & -0.05554461 & -10.6295906 & -22.5234485 & 0.7609417 \\
\hline Trimester 4/3 2009 & 1.39616921 & 6.0834978 & 71.3068595 & 16.520896 \\
\hline Trimester 1 2010/4 2009 & -5.35909174 & 7.36563813 & -25.9893228 & 12.605334 \\
\hline Trimester 2/1 2010 & 4.21815313 & -15.5607365 & -4.28401691 & -17.52114 \\
\hline Trimester 3/2 2010 & 0.85835473 & -7.31799153 & -2.21875498 & 3.1890465 \\
\hline Trimester 4/3 2010 & 3.39476415 & 5.70402503 & 3.58605794 & 10.501585 \\
\hline
\end{tabular}

Table A3

The Growth Rhythm From a Trimester to Another, for Each Type of Expenditure on Taxes

\begin{tabular}{lcccc}
\hline & $\begin{array}{l}\text { Growth rhythm for } \\
\text { tax expenditure }\end{array}$ & $\begin{array}{l}\text { Growth rhythm for } \\
\text { wage tax expenditure }\end{array}$ & $\begin{array}{l}\text { Growth rhythm for pension } \\
\text { contribution expenditure }\end{array}$ & $\begin{array}{l}\text { Growth rhythm for } \\
\text { unemployment expenditure }\end{array}$ \\
\hline Trimester 2/1 2008 & 5.68265016 & 1.02065437 & 16.1142723 & -25.82385 \\
Trimester 3/2 2008 & 12.0820574 & 11.765765 & 13.748802 & 9.2822458 \\
Trimester 4/3 2008 & -0.19701107 & 0.6440255 & -3.1324701 & 24.381547 \\
Trimester 1 2009/4 2008 & -2.30157824 & -25.0472992 & 4.58005748 & 12.299453 \\
Trimester 2/1 2009 & 7.12904538 & 4.87595212 & 12.4530062 & -20.72527 \\
Trimester 3/2 2009 & -0.05554461 & -10.6295906 & -22.5234485 & 0.7609417 \\
Trimester 4/3 2009 & 1.39616921 & 6.0834978 & 71.3068595 & 16.520896 \\
Trimester 1 2010/4 2009 & -5.35909174 & 7.36563813 & -25.9893228 & 12.605334 \\
Trimester 2/1 2010 & 4.21815313 & -15.5607365 & -4.28401691 & -17.52114 \\
Trimester 3/2 2010 & 0.85835473 & -7.31799153 & -2.21875498 & 3.1890465 \\
Trimester 4/3 2010 & 3.39476415 & 5.70402503 & 3.58605794 & 10.501585 \\
\hline
\end{tabular}

Table A4

The Risks Calculated for Each Type of Expenditure, in the Analyzed Period

\begin{tabular}{lllll}
\hline $\begin{array}{l}\text { The risk for the total } \\
\text { expenditure / person }\end{array}$ & $\begin{array}{l}\text { The risk for expenditure on } \\
\text { consumer goods/person }\end{array}$ & $\begin{array}{l}\text { The risk for expenditure } \\
\text { on taxes/person }\end{array}$ & $\begin{array}{l}\text { The risk for expenditure } \\
\text { on long term use goods }\end{array}$ & $\begin{array}{l}\text { The risk for expenditure } \\
\text { on public services }\end{array}$ \\
\hline 22.0287846 & 20.87507 & 116.6408 & 597.26563 & 248.107557 \\
\hline
\end{tabular}

Table A5

The Sensitivity Calculated for Each Type of Expenditure, in the Analyzed Period

\begin{tabular}{llll}
\hline $\begin{array}{l}\text { The sensitivity for expenditure } \\
\text { on consumer goods/person }\end{array}$ & $\begin{array}{l}\text { The sensitivity for } \\
\text { expenditure on taxes/person }\end{array}$ & $\begin{array}{l}\text { The sensitivity for expenditure on } \\
\text { long term use goods }\end{array}$ & $\begin{array}{l}\text { The sensitivity for expenditure } \\
\text { on public services }\end{array}$ \\
\hline 0.105305042 & 0.25906198 & 0.53432052 & 0.10131246 \\
\hline $\begin{array}{l}\text { Table A6 } \\
\text { The Volatility Calculated for Each Type of Expenditure, in the Analyzed Period }\end{array}$ & \\
\hline $\begin{array}{l}\text { The volatility for expenditure } \\
\text { on consumer goods/person }\end{array}$ & $\begin{array}{l}\text { The volatility for expenditure } \\
\text { on taxes / person }\end{array}$ & $\begin{array}{l}\text { The volatility for expenditure on } \\
\text { long term use goods }\end{array}$ & $\begin{array}{l}\text { The volatility for expenditure } \\
\text { on public services }\end{array}$ \\
\hline 0.105305042 & 0.25906198 & 0.53432052 & 0.10131246
\end{tabular}


Table A7

The Values for Each Type of Expenditure on Taxes in the Period 2008-2010, for Each Trimester

\begin{tabular}{llllll}
\hline & $\begin{array}{l}\text { Expenditure on taxes Expenditure on } \\
\text { wperson }\end{array}$ & $\begin{array}{l}\text { Health insurance } \\
\text { contribution }\end{array}$ & $\begin{array}{l}\text { State social insurance } \\
\text { contribution }\end{array}$ & $\begin{array}{l}\text { Unemployment fund } \\
\text { expenses }\end{array}$ \\
\hline 2008 Trimester 2 & 602.64 & 236.51 & 143.29 & 208.09 & 14.75 \\
2008 Trimester 3 & 632.69 & 256.49 & 141.43 & 219.81 & 14.96 \\
2008 Trimester 4 & 660.12 & 272.78 & 142.41 & 230.2 & 14.73 \\
2009 Trimester 1 & 659.46 & 270.33 & 139.68 & 235.02 & 14.43 \\
2009 Trimester 2 & 703.97 & 287.04 & 146.53 & 255.61 & 14.79 \\
2009 Trimester 3 & 696.55 & 284.05 & 144.93 & 252.6 & 14.97 \\
2009 Trimester 4 & 695.62 & 284.4 & 143.67 & 253.27 & 14.28 \\
2010 Trimester 1 & 692.97 & 285.27 & 141.63 & 251.88 & 14.19 \\
2010 Trimester 2 & 691.49 & 283.15 & 141.02 & 252.83 & 14.49 \\
2010 Trimester 3 & 661.35 & 268.38 & 133.93 & 245.48 & 13.56 \\
2010 Trimester 4 & 670.04 & 272.23 & 135.83 & 248.26 & 13.72 \\
\hline
\end{tabular}

Table A8

The Risks Calculated for Each Type of Expenditure on Taxes, in the Analyzed Period

\begin{tabular}{lllll}
\hline $\begin{array}{l}\text { The risk for expenditure } \\
\text { on taxes / person }\end{array}$ & on wage tax & $\begin{array}{l}\text { The expenditure } \\
\text { insurance contribution insurance contribution }\end{array}$ & $\begin{array}{l}\text { The risk for unemployment } \\
\text { fund expenses }\end{array}$ \\
\hline 11.65603 & 18.5823 & 8.781152 & 12.16907 & 10.97704 \\
\hline
\end{tabular}

Table A9

The Sensitivity Calculated for Each Type of Expenditure on Taxes, in the Analyzed Period

\begin{tabular}{llll}
\hline $\begin{array}{l}\text { The sensitivity for } \\
\text { expenditure on wage tax }\end{array}$ & $\begin{array}{l}\text { The sensitivity for health } \\
\text { insurance contribution }\end{array}$ & $\begin{array}{l}\text { The sensitivity for state social } \\
\text { insurance contribution }\end{array}$ & $\begin{array}{l}\text { The sensitivity for } \\
\text { unemployment fund expenses }\end{array}$ \\
\hline 0.3962421 & 0.2362452 & 0.3200744 & 0.0474382 \\
\hline $\begin{array}{l}\text { Table A10 } \\
\text { The Volatility Calculated for Each Type of Expenditure on Taxes, in the Analyzed Period }\end{array}$ & $\begin{array}{l}\text { The volatility for state social } \\
\text { insurance contribution }\end{array}$ & $\begin{array}{l}\text { The volatility for unemployment } \\
\text { fund expenses }\end{array}$ \\
$\begin{array}{l}\text { The volatility for } \\
\text { expenditure on wage tax }\end{array}$ & $\begin{array}{l}\text { The volatility for health } \\
\text { insurance contribution }\end{array}$ & 0.0087524 & 0.0012972 \\
\hline 0.0108352 & 0.0064601 & & 0.0724
\end{tabular}

